among young and presumably strong and healthy adults. South Africa and Tangier are also experiencing severe epidemics.

While in previous epidemics the general progress of influenza has been westwards from Asiatic and European Russia, the epidemic this year was first reported in Spain and travelled northward. It is to be noted, however, that the war has fundamentally changed the general direction of European traffic-that from East to West being suspended, while the North and South traffic has been greatly augmented. It has to be remembered, too, that Chinese and other Eastern coolies have furnished Labour battalions behind the lines on the Western front, and it may be quite likely, therefore, that the disease has been imported from the East in this manner.

With regard to the nature of epidemic influenza, it is undoubtedly a fever of a highly infectious or contagious character, and, therefore, caused by some micro-organism. In the epidemic of the 'nineties Pfeiffer discovered a minute bacillus, difficult to grow except on certain specially prepared culture media, and even then yielding only very delicate growths, and unstained by the Gram method of staining. This is the influenza bacillus which has ever since been regarded as the causative microbe of epidemic influenza. In the epidemic of this year, however, Spanish, British, and German investigators have failed to find the influenza bacillus except in quite a minority of cases. The principal bacteriological findings reported are microbes belonging to the coccus class, either Gram-negative or Gram-positive cocci, and in some of the fatal cases streptococci have been present in the blood.

The difference in the bacteriological findings between the 'ninety and the present epidemics suggests that epidemic influenza, so-called, is not a single disease. We have a parallel to this in the case of typhoid and paratyphoid fevers, which in symptoms closely resemble each other, but which are due to distinct microbial agents. There are also certain differences in the symptoms present in different influenza epidemics which point to the same conclusion.

The principal factor influencing the spread of influenza seems to be close aggregation of individuals. It is the crowded office, workshop, barrack, or camp that suffers most from the ravages of influenza. Dilution with plenty of air mitigates the infectious properties, and free ventilation is therefore important. In the July outbreak favourable reports were given of the value of systematic spraying of the air of offices and workshops with an atomiser spray, using some volatile disinfectant, such as bacterol, in largely preventing the spread of infection. Fatigue and debility are always conducing factors to infection, and the young and the old are generally more prone to contract the disease. Whether any drug has really any power to prevent infection is questionable, but in the 'ninety epidemics there was a general impression that systematic daily doses of quinine were of some use.

R. T. Hewlett.

\section{THE SALTERS' INSTITUTE OF INDUS-} TRIAL CHEMISTRY.

'THE Salters' Company has during many years given evidence of its interest in the promotion of scientific education and research by the provision of fellowships tenable by post-graduate workers. It has now taken a further very important step in announcing a scheme for the establishment of an institute to be called "The Salters' Institute of Industrial Chemistry." The offices of the institute will be for the present at the Salters' Hall, and the scheme will be administered by a director, who will be selected on the ground of qualifications based on a distinguished academic career in chemistry coupled with extensive technical experience. An Advisory Board composed of representatives of the Salters' Company, the universities, and the Association of British Chemical Manufacturers is also under consideration.

The Company proposes to establish two types of fellowship, for which post-graduate students of British nationality will be eligible whether graduates of a British university or of a university in the United States or elsewhere. There are to be (I) fellowships to enable post-graduate students to continue their studies at an approved university or other institution under the general supervision of the director of the institute, and (2) industrial fellowships to enable suitably equipped chemists to carry on research for any manufacturer under an agreement entered into jointly by the institute, the manufacturer, and the fellow.

It will be observed that the Company does not at present contemplate the erection of any building or the equipment of any laboratory. Its aim is, therefore, somewhat different from that of the founders of such establishments as the DavyFaraday Laboratory attached to the Royal Institution in London, or the Kaiser Wilhelm Institute opened in I912 near Berlin. The intention is to add to the number of first-rate chemical technologists available for the service of industry in this country, a class of men which at present scarcely exists and is sorely needed. It is hoped to offer such attractions to some of the best students that on completing their university course they will seek to apply their knowledge to manufacture and industry generally, and that employers will recognise promptly the necessity for such assistance so that openings for such men with suitable remuneration will be provided concurrently with the supply. Hitherto almost the only career available for the honours graduate in chemistry has been in connection with the teaching profession. Probably in future such men will be divided into two classes according to their personal predilections, some going to the works, while others will prefer teaching. In both directions the opportunities provided have been insufficient in number and inadequate in remuneration, so that many cases have occurred in which a man with distinct scientific gifts has been forced by circumstances NO. 2556 , VOL. IO2] 
to seek employment in other directions, and science has been consequently the poorer.

The fundamental idea which has inspired the Salters' Company may be illustrated by one or two examples. Suppose a man to have taken his degree with distinction in chemistry, and in physiology as a second subject. Elected to a Salters' fellowship, he may undertake a research on some subject of a biochemical nature. This may be carried on at his own university or at any other possessing a special school for this class of work in England or some other country. In due time arrangements may be made by the director for the fellow to take a course of chemical engineering, perhaps in America, and afterwards to obtain technical and industrial experience. In a very short time a man so trained and experienced will be in a position to demand, and will certainly be worth, a very high salary. It would be easy to provide a similar course with the necessary modifications adapted to the case of a man whose original bent is in the direction of physical chemistry or pure organic or metallurgical chemistry. The printed scheme issued by the Salters' Company gives no information as to the pecuniary value of the proposed fellowships. In estimating the annual amount which should be assigned to each fellowship, it must be remembered that the holder, while required to live simply and carefully, must be free from difficulties about books, travelling expenses, and laboratory outlay. Probably $300 l$. a year under present conditions and for some time to come will not be found too much, though perhaps expenses will depend to some extent on whether the student remains at home or is required to reside at a foreign university or centre. When operations are to commence at the institute will depend on the discovery of the right man for the office of director, and doubtless he will have a good deal to say about working details.

The two classes of fellowship referred to in the scheme have been in principle anticipated. For the former, which provides for post-graduate study without at first direct reference to technical applications, the Ramsay Memorial, which has been before the public for the greater part of the last two years, has adopted essentially the same plan, and is only waiting for funds to carry it into effect.

With regard to the institution of industrial fellowships, nothing of the kind has yet been attempted in this country. But the Kennedy Duncan scheme in connection with the Universities of Kansas and Pittsburgh has been in operation for some few years, and is reported to have been satisfactory and successful. Mention of these facts, however, is not intended to disparage in any way the wise forethought and liberal intentions of the Salters' Company, which, by the action now contemplated, is rendering a very important service to national interests, both by the example thus set and by the generous application of its funds.

One other point may here be mentioned. The scheme under consideration seems to avoid the difficulty which has always been associated with NO. 2556 , VOL. IO2 other schemes for the encouragement of postgraduate work-namely, that the career of the student after the first few years was indeterminate, and often ended in disappointment. The scheme, once talked of, for providing valuable fellowships with the object of tempting a few specially endowed researchers to devote the rest of their lives to research seems to have been lost sight of, or, after consideration, to have been given up.

It is, however, to be hoped that nothing in the plans proposed for associating science with industry will result in discouragement to scientific genius. Researches undertaken with specific objects, especially with a view to improvements in manufacturing processes or to the invention of new ones, and in the investigation of properties of materials and products, will probably not lead to the discovery of new fundamental principles. In the past these have almost always been the fruit of labours undertaken under the stimulus of that kind of curiosity concerning Nature, her laws, purposes, and operations, which is sufficient to satisfy the ambition of a Davy or a Faraday. Whatever Ramsay might have done had he devoted his working life to researches designed to assist industry, the results of his studies concerning the source and properties of the inert gases, themselves of no use in human affairs, are of greater permanent interest and importance by reason of the new light thrown on the nature of the elements and the constitution of matter. After all, a knowledge of the materials and powers in which life is immersed, and of which it is a part, is in the long run more useful than the applications which may be made to the purposes of mankind. The student of Nature is concerned only about the means of carrying on his work without anxiety as to the future of himself or his family. His discoveries cannot immediately become the subjects of sale or pecuniary reward, and as a rule he does not look for anything of the sort. It will, however, not be forgotten that for the few there are the Nobel prizes.

\section{THE RECONSTRUCTION OF THE FISHING INDUSTRY.}

$\mathrm{T} T$ is no secret that a most vigorous propaganda for the reconstruction of the entire fabric of fishery control is now being carried on by those engaged in the industry, and that this movement gathers force as the end of the war appears to come nearer. The English propaganda takes the form of proposals for the unification of fishery control by the creation of a Ministry having all the powers now exercised by branches of several Public Departments and by the local Fishery Committees. Its suggestions relate mainly to administrative and regulative reforms, to problems of marketing, transport, distribution, exploitation, and technical education. The Scottish proposals, which have just become public, ${ }^{1}$ devote but slight attention to administrative changes, but

1 Memorandum on the Reconstruction of the Fishing Industry after the War. Prepared by the Scottish Steam Drifters' Association, Aberdeen, at
the Drily Journal Office, September, 1918 . 